Esta publicación cientifica en formato digital es continuidad de la revista impresa ISSN-Versión Impresa 0798-1406 / ISSN-Versión on line 2542-3185Depósito legal pp
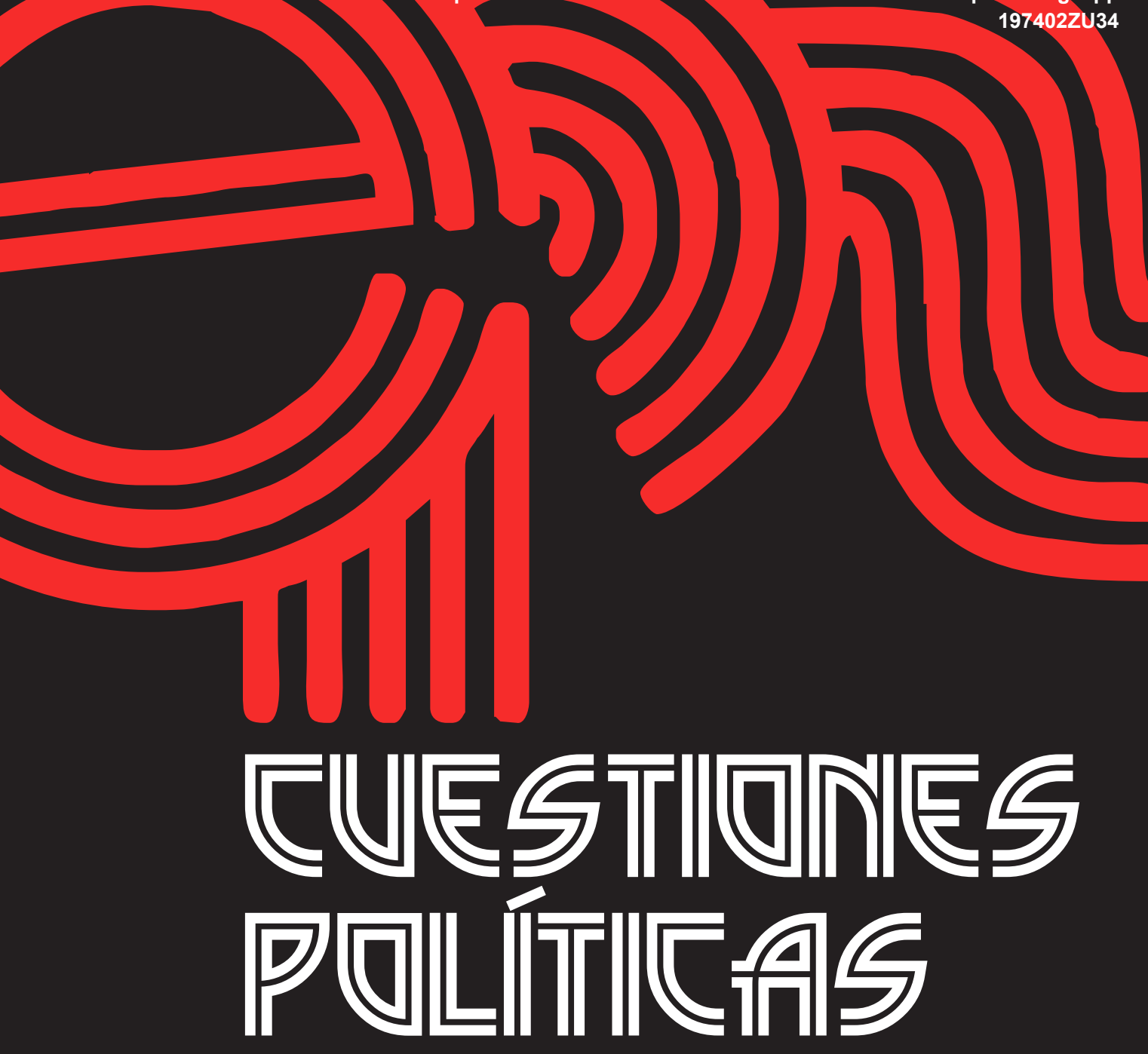

Instituto de Estudios Políticos y Derecho Público "Dr. Humberto J. La Roche" de la Facultad de Ciencias Jurídicas y Políticas de la Universidad del Zulia Maracaibo, Venezuela
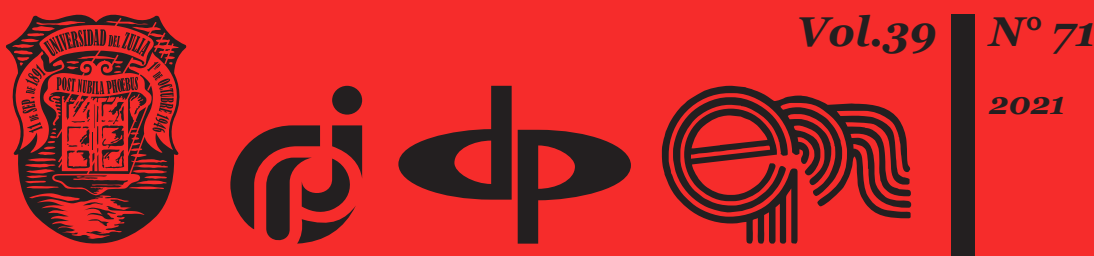


\title{
Legality of Applying Coercive Medical Measures in Criminal Law
}

\section{DOI: https://doi.org/10.46398/cuestpol.3971.06}

\author{
Iryna $V$. Kalinina * \\ Volodymyr M. Kupriienko ** \\ Iryna I. Shulhan *** \\ Dmytro O. Pylypenko **** \\ Olena A. Kozeratska $* * * * *$
}

\begin{abstract}
The objective of the study was to determine the legality of the application of coercive medical measures and to develop recommendations to improve the legislative regulation of their use. The study included data on the number of offenders with mental disorders; the empirical background was the decision of the European Court of Human Rights on the application of coercive medical measures; provisions of the legislation of 31 countries. Methods of system approach, comparison, descriptive analysis, pragmatic approach, prognosis were used. The national criminal law of most states regulates the application of coercive medical measures to persons who have committed a crime in a state of limited sanity or insanity or have acquired it before sentencing or during the execution of the sentence, but its practical application causes several complications. It is concluded that the legislative definition of coercive medical measures corresponds to human rights legislation. But there are problems with its practical application. Proposals were made to amend national and international legislation: to broaden the range of grounds for the application of coercive medical measures; regulate
\end{abstract}

* PhD in Law, Head of the Department of the Special-Law Disciplines, Faculty of Law and Public Management, Donetsk State University of Management, 87513, Mariupol, Ukraine. ORCID ID: https:// orcid.org/oooo-0001-5199-9545

** PhD in Law, Associate Professor, Department of Criminal Law and Procedure of the Kyiv University of Law of the National Academy of Sciences Ukraine, 03142, Kyiv, Ukraine. ORCID ID: https://orcid. org/oooo-0003-1601-0679

*** PhD in Law, Assistant, Department of Criminal Law and Procedure, Institute of Law, Psychology and Innovative Education, Lviv Polytechnic National University, 79013, Lviv, Ukraine. ORCID ID: https:// orcid.org/oooo-0002-9623-3495

**** PhD in Law, Associate Professor, Department of Criminal Law Disciplines, Faculty №2, Kryvyi Rih Educational and Scientific Institute, Donetsk State University of Internal Affairs, 500oo, Kryvyi Rih, Ukraine. ORCID ID: https://orcid.org/oooo-0003-1299-6178

***** PhD in Medicine, Associate Professor, Department of Criminalistics and Criminal Procedure of the Institute of Law of Taras Shevchenko National University, 01601, Kyiv, Ukraine; Head of the Department of Forensic Psychiatric Examination of the State Institution "Center for Mental Health and Monitoring of Drugs and Alcohol of the Ministry of Health of Ukraine”, 04050, Kyiv, Ukraine. ORCID ID: https://orcid.org/oooo-0oo1-7957-9657 
the possibility of early termination of a coercive medical measure; oblige the courts to determine the appropriate terms.

Keywords: coercive medical measures; mental illness; mental disorder; criminal law measures; human rights.

\section{Legalidad de la Aplicación de Medidas Médicas Coercitivas en el Derecho Penal}

\section{Resumen}

El objetivo del estudio fue determinar la legalidad de la aplicación de medidas médicas coercitivas y desarrollar recomendaciones para mejorar la regulación legislativa de su uso. El estudio incluyó datos sobre el número de delincuentes con trastornos mentales; el antecedente empírico fue la decisión del Tribunal Europeo de Derechos Humanos sobre la aplicación de medidas médicas coercitivas; disposiciones de la legislación de 31 países. Se utilizaron métodos de enfoque de sistema, comparación, análisis descriptivo, enfoque pragmático, pronóstico. La legislación penal nacional de la mayoría de los estados regula la aplicación de medidas médicas coercitivas a personas que han cometido un delito en un estado de cordura o demencia limitada, o lo han adquirido antes de dictar sentencia o durante el cumplimiento de esta, pero su aplicación práctica provoca una serie de complicaciones. Se concluye que la definición legislativa de medidas médicas coercitivas corresponde a la legislación en materia de derechos humanos. Pero existen problemas con su aplicación práctica. Se formularon propuestas para modificar la legislación nacional e internacional: ampliar la gama de motivos para la aplicación de medidas médicas coercitivas; regular la posibilidad de terminación anticipada de una medida médica coercitiva; obligar a los tribunales a determinar los términos adecuados.

Palabras clave: medidas médicas coercitivas; enfermedad mental; trastorno mental; medidas de derecho penal; derechos humanos.

\section{Introduction}

The application of certain criminal law measures within the limits of condemnation of criminal behaviour of a person on behalf of the state is one of the forms of realisation of criminal liability. Naturally, the most commonly used and most severe form of the state's response to a criminal offense is 
the application of punishment to the perpetrator. But in law enforcement practice, there are situations when a person guilty of a crime cannot be punished, and his/her state of health (physical, mental or psychological) requires the application of other criminal law measures. One of the types of such criminal law measures that are not criminal punishment is coercive medical measures (Lapshin and Korneev, 2019).

The instrument of state influence includes the mechanisms, which provide for the restriction of certain human rights and freedoms, although it is recognised as the highest state value and object of protection. The legal grounds for restricting human rights and freedoms are criminal law measures applied to persons who have committed a crime and are found guilty of it on the basis of a court decision. The use of criminal law measures such as coercive medical measures due to social necessity - to respond to the criminal behaviour of persons who have committed a crime in a state of limited sanity or acquired such a state, or the state of insanity, during pretrial and judicial investigation (Ferracuti et al., 2019). In this regard, the criminal law of many countries contains rules that determine the conditions and grounds for the application of such criminal law measures (Markava, 2017).

Besides, European legislation also establishes the legality of compulsory medical care for persons suffering from certain diseases in terms of guaranteeing human rights (Israelsson et al., 2015). But in practice, there are often difficulties in addressing the issue of possibility and necessity of applying these measures to perpetrators (Losych and Rutvian, 2019). These complications are especially often associated with the establishment of the actual occurrence of such a mental disorder or other morbid condition in the person who committed the crime (Kooijmans and Meynen, 2017).

But it is quite logical that other questions arise: Is it possible to apply coercive medical measures, including compulsory treatment, to persons who have committed a crime in a psycho-physiological state, which does not exclude criminal liability? whether there is a violation of human rights in such a case; Does the application of coercive medical measures against the defendants justify itself, is it effective?

\section{Literature Review}

Medical science studies the impact of coercive medical measures, their effectiveness and applicability to patients with mental illness or mental disorders (Zhang et al., 2015); the procedure for the application of mandatory medical measures for insane (Zhumanbaeva and Alimkulov, 2019); the effectiveness of compulsory treatment of drug addicts (Werb et al., 2016); the effectiveness of specialised centres for the maintenance and 
treatment of drug addicts is analysed on the example of East and Southeast Asia (Kamarulzamana and McBrayer, 2015).

The current state and prospects of compulsory treatment in psychiatric institutions of persons in need of such treatment are also studied from the perspective of ethical considerations and in order to determine the advantages and disadvantages (Saya et al., 2019).

The effectiveness of the application of coercive medical measures is studied in legal science, in particular in the field of criminal law. Attention is paid to compliance with European standards of respect for human rights in the application of compulsory medical measures in criminal law and criminal proceedings (Tyshchenko et al., 2019). The effectiveness of compulsory hospitalization of juvenile offenders with drug addiction is also studied in order to prevent their further criminal activity (on the example of Brazil) (Dos Reis and Guareschi, 2016); the need for treatment of prisoners with drug or alcohol addiction is analysed (Brochu, and Levesque, 1991). It is emphasized that compulsory treatment of drug and alcohol addicts, including criminals, is not always effective when it is involuntary (on the example of the People's Republic of China (Xiong and Jia, 2019), Sweden (Lövgren, 2021). The need to establish stricter criteria for compulsory treatment, including criminals, is also emphasised (Zinkler, 2016).

At the same time, a large number of studies does not mean that the research of problematic issues related to the application of medical measures in criminal law is complete and comprehensive. In particular, almost no attention was paid to the legality of the application of coercive medical measures, compulsory medical treatment, and involuntary hospitalization to persons who committed a crime. Although the problem of the admissibility of involuntary medical intervention in the rehabilitation of criminals has been studied (Pugh and Douglas, 2016); the issue of applying coercive medical measures was considered in studying the experience of the interaction of law enforcement officers with citizens, organizations and institutions for compulsory treatment of persons in need for such a treatment, including criminals (Soares and Pinto da Costa, 2019), this issue was not clearly covered.

Given the urgency of the study, as well as the unresolved issues related to the application of coercive medical measures to perpetrators, the aim of this study will be to determine the legality of these measures and develop recommendations to improve their legal regulation. The aim of the study provided for the following objectives: determine the legal grounds for their application and proposals for their legislative enshrinement at the level of international and national legislation. 
Iryna V. Kalinina, Volodymyr M. Kuprïenko, Iryna I. Shulhan, Dmytro O. Pylypenko y Olena A. Kozeratska

130

Legality of Applying Coercive Medical Measures in Criminal Law

\section{Methodology and Methods}

This study was conducted in a clear sequence, following the stages of studying the issue, based on the logic of the presentation of the material, in order to achieve the aim set in the article and fulfil its objectives. These stages were: formulation of topic and defining the scope of the study; search and selection of references; selection and study of statistics; analysis of the material presented in selected references and evaluation of the results of these studies; identification of unresolved problems of legality of application of coercive medical measures in criminal law; determining the aim of the article; drawing conclusions and practical recommendations for solving the problems chosen for research; outlining prospects for further research in this area.

This study used statistics on the number of criminals with mental disorders; the empirical background of the study was the decisions of the ECHR on the application of coercive medical measures and compulsory treatment (30 decisions were analysed); expert opinions on the expediency and necessity of applying coercive medical measures to persons who have committed a crime in the relevant condition. The norms of international and national regulatory legal acts, which define certain aspects of the principles and procedure for the application of coercive medical measures were studied in detail in order to identify gaps and make proposals for their elimination both in international norms and in national legislation of individual countries to increase the effectiveness of these criminal law restrictive measures.

The legal framework of the study was the provisions of international regulations: UN General Assembly Resolution 46/119 of December 17, 1991, which approves the Principles for the Protection of Persons with Mental Illness and the Improvement of Mental Health Care, the European Convention for the Protection of Human Rights and Fundamental Freedoms of 1950 (hereinafter - the Convention), the International Covenant on Civil and Political Rights of 1966 . The national legislation of 31 countries was considered to analyse the provisions of national legislation that determine the procedure and grounds for the application of coercive medical measures in criminal law and compulsory treatment.

The study involved the following methods to achieve the aim:

- a systemic approach was used to analyse the grounds for the application of coercive medical measures to criminals as a system of interrelated objective and subjective circumstances.

- comparison was used for comparative analysis of the grounds for the application of coercive medical measures enshrined in the criminal law of individual countries. 
- descriptive analysis was used to arrange, classify and summarise information on the public danger of leaving persons who committed a crime in a state of insanity or limited sanity, or acquired such a state before sentencing or while serving a sentence, without medical care and treatment.

- pragmatic approach to data collection and analysis was used to determine the main grounds for the application of coercive medical measures to persons who committed a crime in a state of sanity or limited sanity, or acquired such a state before sentencing or while serving a sentence.

- forecasting approach was used to develop proposals and recommendations for improving the legislation to establish criteria and grounds for the application of cohesive medical measures in criminal law.

\section{Results}

Prosecution of perpetrators is always accompanied in practice by a number of problems related to the application of certain criminal law measures to them. One such problem is the application of coercive medical measures to persons who have committed crimes in a state of insanity or limited sanity, or acquired such a state before sentencing or while serving a sentence. According to statistics, the commission of crimes by persons in a state of insanity or limited sanity has always been quite common. For example, U.S. statistics show that approximately $16 \%$ of all inmates had serious mental illness (Mental Illness Policy, 2005). According to other data, about $25 \%$ of criminals suffer from mental disorders (Morgan et al., 2012). Moreover, 10-12\% of murders are committed by mentally ill persons (Russia) (Bersh, 2017). At the same time, the increase in the number of mental health care centres has a positive impact and helps to reduce crime by $1.7 \%$ in the relevant regions (on the example of the United States) (Deza et al., 2019).

UN General Assembly Resolution of December 17, 1991 approved the Principles for the Protection of Persons with Mental Illness and the Improvement of Mental Health Care, which states that every patient should have the right to treatment and care as far as possible in the society in which he or she lives (Principle 7: Role of Society and Culture). The legality of the use of compulsory treatment of persons suffering from certain types of mental disorders, including persons who have committed a crime, has been recognized in this Principle. 
In order to ensure the application of coercive medical measures and compulsory medical treatment to persons who have committed a crime in a state of limited sanity or insanity, or acquired such a state before sentencing or while serving a sentence, coercive medical measures and compulsory treatment, the national criminal law of the vast majority of states regulates the application of these criminal law measures. These rules establish the procedure and grounds for the application of these measures to offenders who have committed a crime in a state of limited sanity or insanity or acquired such a state before sentencing or while serving a sentence (see Table 1).

\section{Table 1. Norms of the national criminal legislation regulating application of coercive medical measures}

\begin{tabular}{|l|l|}
\hline Country & Provisions of criminal legislation \\
\hline Germany & $\begin{array}{l}\text { SIXTH TITLE MEASURES OF REHABILITATION AND } \\
\text { INCAPACITATION } \\
\text { Section 61 Overview } \\
\text { Section 62 Principle of proportionality } \\
\text { Section 63 Mental hospital order } \\
\text { Section 64 Custodial addiction treatment order } \\
\text { Section 66 Detention for the purpose of incapacitation } \\
\text { Section 66c Organisation of detention for the purposes of } \\
\text { incapacitation and of antecedent imprisonment } \\
\text { Section 67 Sequence of enforcement } \\
\text { Section 67a Transfer to another measure } \\
\text { Section 67c Deferred start date of detention } \\
\text { Section 67d Duration of detention }\end{array}$ \\
\hline France & $\begin{array}{l}\text { SECTION II PERSONALIZATION OF PENALTIES } \\
\text { Subsection 1 Semi-detention } \\
\text { ARTICLE 132-25 } \\
\text { ARTICLE 132-26 } \\
\text { ARTICLE 132-26-1 } \\
\text { ARTICLE 132-26-2 } \\
\text { Subsection 2 Division of penalties } \\
\text { ARTICLE 132-45 }\end{array}$ \\
\hline Albania & $\begin{array}{l}\text { CHAPTER V PUNISHMENTS } \\
\text { Article 46 Medical and educational measures (Amended by law } \\
\text { no 36/2017) } \\
\text { CHAPTER VII ALTERNATIVES TO IMPRISONMENT } \\
\text { SENTENCES } \\
\text { Article 58 Open prison }\end{array}$ \\
\hline Switzerland & $\begin{array}{l}\text { Chapter Two: Measures Section One: Therapeutic Measures and } \\
\text { Indefinite Incarceration } \\
\text { Art. 56-Art. 64c }\end{array}$ \\
\hline
\end{tabular}




\begin{tabular}{|c|c|}
\hline Turkey & $\begin{array}{l}\text { Part } 2 \text { Security Measures } \\
\text { Article } 57 \text { Security Measures Specific to the Mentally Disordered }\end{array}$ \\
\hline $\begin{array}{l}\text { Russian } \\
\text { Federation }\end{array}$ & $\begin{array}{l}\text { Chapter 15. Compulsory Measures of a Medical Nature } \\
\text { Article 97. Grounds for the Application of Compulsory Measures } \\
\text { of a Medical Nature } \\
\text { Article 98. The Purposes of the Application of Compulsory } \\
\text { Measures of a Medical Nature } \\
\text { Article 99. Compulsory Medical Measures } \\
\text { Article 101. Compulsory Treatment in a Mental Hospital } \\
\text { Article 102. The Prolongation, Change, or Termination of the Use } \\
\text { of Compulsory Medical Measures } \\
\text { Article 103. Set-off of the Time of Application of Compulsory } \\
\text { Medical Measures } \\
\text { Article 104. Compulsory Medical Measures Joined with the } \\
\text { Execution of Punishment }\end{array}$ \\
\hline $\begin{array}{l}\text { Republic of } \\
\text { Uzbekistan }\end{array}$ & $\begin{array}{l}\text { SECTION SEVEN. COMPULSORY MEDICAL MEASURES } \\
\text { CHAPTER 17. GROUNDS FOR AND APPLICATION OF } \\
\text { COMPULSORY MEDICAL MEASURES } \\
\text { Article 91. Purposes of Compulsory Measures } \\
\text { Article 92. General Grounds for Application of Compulsory } \\
\text { Medical Measures } \\
\text { Article 93. Types of Compulsory Medical Measures } \\
\text { Article 94. Application of Compulsory Medical Measures } \\
\text { Article 95. Extension, Altering, and Discontinuation of } \\
\text { Application of Compulsory Medical Measure } \\
\text { Article 96. Application of Compulsory Medical Measures } \\
\text { to Persons Suffering Alcohol, Drugs, and Toxic Substances } \\
\text { Addiction }\end{array}$ \\
\hline Georgia & $\begin{array}{l}\text { CHAPTER XIV - Release from Punishment } \\
\text { Article } 74 \text { - releasing from punishment due to illness or old age }\end{array}$ \\
\hline $\begin{array}{l}\text { Republic of } \\
\text { Azerbaijan }\end{array}$ & $\begin{array}{l}\text { Chapter 15. Compulsory measures of medical nature } \\
\text { Article 93. Bases of application of compulsory measures of } \\
\text { medical nature } \\
\text { Article 93-1. The use of compulsory medical measures in respect } \\
\text { of persons who are in need of treatment for alcoholism or drug } \\
\text { addiction } \\
\text { Article 94. Purposes of application of compulsory medical } \\
\text { measures to the persons suffering from mental disorders } \\
\text { Article 95. Kinds of compulsory measures of medical nature, } \\
\text { appointed to the persons suffering from mental disorder } \\
\text { Article 96. Out-patient compulsory supervision and treatment at } \\
\text { psychiatrist } \\
\text { Article 97. Mandatory treatment in psychiatric hospital } \\
\text { Article 98. Extension, change and cancellation of compulsory } \\
\text { measures of medical nature, appointed to the persons suffering } \\
\text { from mental disorder } \\
\text { Article 99. Offset of time on application of compulsory measures } \\
\text { of medical character, appointed to the persons suffering from } \\
\text { mental disorders }\end{array}$ \\
\hline
\end{tabular}


Iryna V. Kalinina, Volodymyr M. Kuprïenko, Iryna I. Shulhan, Dmytro O. Pylypenko y Olena A. Kozeratska

\begin{tabular}{|c|c|}
\hline $\begin{array}{l}\text { Republic of } \\
\text { Kazakhstan }\end{array}$ & $\begin{array}{l}\text { SECTION 7. COMPULSORY MEASURES OF MEDICAL } \\
\text { NATURE } \\
\text { Article 91. Grounds of application of compulsory measures of } \\
\text { medical nature } \\
\text { Article } 92 \text {. Purposes of application of compulsory measures of } \\
\text { medical nature } \\
\text { Article 93. Types of compulsory measures of medical nature } \\
\text { Article 94. Compulsory out-patient observance and treatment on } \\
\text { the by a psychiatrists } \\
\text { Article } 95 \text {. Compulsory treatment in a mental hospital } \\
\text { Article 96. Extension, change and cancellation of compulsory } \\
\text { measures of medical nature } \\
\text { Article } 97 \text {. Imposition of punishment after application of } \\
\text { compulsory measures of medical nature } \\
\text { Article 98. Compulsory measures of medical nature, connected } \\
\text { with execution of punishment }\end{array}$ \\
\hline $\begin{array}{l}\text { Republic of } \\
\text { Bulgaria }\end{array}$ & $\begin{array}{l}\text { Chapter Eleven COMPULSORY MEDICAL MEASURES } \\
\text { Article } 89 \text { - Article } 92\end{array}$ \\
\hline Denmark & $\begin{array}{l}\text { Chapter } 9 \text { Other Legal Consequences of a Punishable Act } \\
\S 68\end{array}$ \\
\hline Netherlands & $\begin{array}{l}\text { Chapter Two. Admission to a Psychiatric Hospital and Detention } \\
\text { under an Entrustment Order } \\
\text { Art. 37-Art.37e }\end{array}$ \\
\hline Spain & $\begin{array}{l}\text { Chapter II. On application of security measures } \\
\text { Subchapter I. On measures depriving of freedom } \\
\text { Art.101- Art. } 104\end{array}$ \\
\hline Ukraine & $\begin{array}{l}\text { Chapter XIV. COMPULSORY MEDICAL MEASURES AND } \\
\text { COMPULSORY TREATMENT } \\
\text { Article 92. Definition and purpose of compulsory medical } \\
\text { measures } \\
\text { Article 93. Persons subjected to compulsory medical measures } \\
\text { Article 94. Types of compulsory medical measures } \\
\text { Article 95. Continuation, change or discontinuation of } \\
\text { compulsory medical measures } \\
\text { Article 96. Compulsory treatment }\end{array}$ \\
\hline $\begin{array}{l}\text { Republic of } \\
\text { Latvia }\end{array}$ & $\begin{array}{l}\text { Chapter VIII Compulsory Measures of a Medical Nature } \\
\text { Section 68. Compulsory Measures of a Medical Nature } \\
\text { Section 69. Determination of Compulsory Measures of a Medical } \\
\text { Nature for Persons in a State of Mental Incapacity } \\
\text { Section 69. 1 Provision of Compulsory Measures of a Medical } \\
\text { Nature after Several Rulings } \\
\text { Section 70. Provision of Compulsory Measures of a Medical } \\
\text { Nature for Persons in a State of Diminished Mental Capacity }\end{array}$ \\
\hline $\begin{array}{l}\text { Republic of } \\
\text { Poland }\end{array}$ & $\begin{array}{l}\text { Chapter X. Preventive Measures } \\
\text { Article } 93 \text { - Article } 94\end{array}$ \\
\hline Sweden & $\begin{array}{l}\text { Chapter } 31 \text { - On special care orders in certain cases } \\
\text { Section } 3 \\
\text { Chapter } 26 \text { - On imprisonment } \\
\text { Section } 16 \\
\text { Section } 22\end{array}$ \\
\hline
\end{tabular}

Source: own elaboration. 
The grounds and procedure for the application of coercive medical measures and compulsory treatment to persons who have committed a crime in a state of limited sanity or insanity, or acquired such a state before sentencing or while serving a sentence are also established in a number of other national regulations, which the court relies on its activities (see Table 2).

\section{Table 2. Regulation of involuntary placement in medical institutions and involuntary treatment (EU legislation)}

\begin{tabular}{|c|c|}
\hline Country & Regulatory legal acts \\
\hline Austria & $\begin{array}{l}\text { Compulsory Admission Act (CAA) (Unterbringungsgesetz, UbG), } \\
\text { BGBł 155/1990 }\end{array}$ \\
\hline Belgium & $\begin{array}{l}\text { Act concerning the protection of the person of the mentally ill } \\
\text { (26 June 1990) (Lol relative à la protection de la personne des } \\
\text { malades mentaux) Patient's rights Act ( } 22 \text { August 2002) (Loi } \\
\text { relative aux droits des patients) }\end{array}$ \\
\hline Bulgaria & Chapter II Health Act (Закон за здравето), 1 January 2005 \\
\hline $\begin{array}{l}\text { Czech } \\
\text { Republic }\end{array}$ & $\begin{array}{l}\text { Healthcare Act Zákon č. 20/1966 Sb., o péči o zdraví lidu } \\
\text { (1 July 1966); Civil Procedure Code (Zákon č. 99/1963 Sb., } \\
\text { občanský soudní ŕád), Act No. 99/1963 Coll. }\end{array}$ \\
\hline Germany & $\begin{array}{l}\text { § } 1906 \text { Civil Code (BGB) introduced by the Betreuungsgesetz } \\
\text { (BtG) (Custodianship Act) of 12 September 1990, (enforced } \\
\text { 1 January 1992); Placement under public law governed by states } \\
\text { (Länder) laws }\end{array}$ \\
\hline Denmark & $\begin{array}{l}\text { Act No. 331, } 24 \text { May } 1989 \text { on deprivation of liberty and other } \\
\text { coercion in psychiatry }\end{array}$ \\
\hline Estonia & $\begin{array}{l}\text { § 19-20 Social Welfare Act (SWA) (Riigikantselei (6 March 1995) } \\
\text { Riigi Teataja I), 21, 323, (8 February 1995); § 533-543 Code of } \\
\text { Civil Procedure (CCP) (Tsiviilkohtumenetluse seadustik), } 20 \\
\text { April } 2005\end{array}$ \\
\hline Spain & $\begin{array}{l}\text { Article } 763 \text { Civil Procedure Act (Ley } 1 / 2000 \text {, de } 7 \text { de enero, de } \\
\text { Enjuiciamiento Civil); Act of the Autonomy of the Patient Law } \\
\text { 41/2002 (14 November 2002) }\end{array}$ \\
\hline France & Public Health Code, Articles L.3212-1 to L.3213-11 \\
\hline Hungary & $\begin{array}{l}\text { Healthcare Act (1997. évi CLIV. törvény az egészségügyrõl) (15 } \\
\text { December 1997) }\end{array}$ \\
\hline Italy & Article 33-35 Law n. 833/1978 (23 December 1978) \\
\hline Latvia & $\begin{array}{l}\text { Article } 68 \text { Medical Treatment Law (Ārstniecības likums) (26 } \\
\text { February 1998) }\end{array}$ \\
\hline Lithuania & $\begin{array}{l}\text { Law on Mental Health Care/1995, Nr. I-924, (Psichikos sveikatos } \\
\text { priežiūros istatymas, Zin., 1995, Nr. 53-1290). Available in EN } \\
\text { (without amendments: www3.Irs.lt/pls/inter2/dokpaieska. } \\
\text { showdoc_e?p_id=39589) }\end{array}$ \\
\hline
\end{tabular}


Iryna V. Kalinina, Volodymyr M. Kuprïenko, Iryna I. Shulhan, Dmytro O. Pylypenko y Olena A. Kozeratska

\begin{tabular}{|l|l|}
\hline Luxembourg & $\begin{array}{l}\text { Luxembourg law on hospitalisation of persons with mental } \\
\text { disorders without their consent (relative à l’hospitalisation sans } \\
\text { leur consentement de personnes atteintes de troubles mentaux) } \\
\text { (10 December 2009) }\end{array}$ \\
\hline Malta & $\begin{array}{l}\text { Mental Health Act Chapter } 262 \text { of the Laws of Malta (adopted in } \\
\text { 1976) }\end{array}$ \\
\hline Netherlands & $\begin{array}{l}\text { The 1992 Psychiatric Hospitals (Compulsory Admissions) Act } \\
\text { (enforced January 1994) }\end{array}$ \\
\hline Poland & $\begin{array}{l}\text { Law on Protection of Mental Health, (Ustawa o wychowaniu w } \\
\text { trzeźwości i przeciwdziałaniu alkoholizmowi) Dz. U. 1994 No 111 } \\
\text { Item 53519, 19 August 1994 }\end{array}$ \\
\hline Portugal & \begin{tabular}{l} 
Article 12 Law on mental health 36/98, 24 July 1998 \\
\hline Romania
\end{tabular}$\quad \begin{array}{l}\text { Mental Health Law (Law 487/2002), 11 July 2002; Law on } \\
\text { Patient's Rights No. 46/2002 (Legea drepturilor pacientului Nr. } \\
\text { 46/2002) }\end{array}$ \\
\hline Slovakia & $\begin{array}{l}\text { Article 191a-191g Civil Procedure Code (Zákon 99/1963) } \\
\text { 4 December 1963; 1 6 and 8 Health Care Act (Zákon 576/2004) } \\
\text { 21 October 2004 }\end{array}$ \\
\hline Great Britain & $\begin{array}{l}\text { Mental Health Act 1983; Mental Health (Care and Treatment) } \\
\text { (Scotland) Act 2003 asp. 13; Mental Health (Northern Ireland) } \\
\text { Order 1986 No. 595 (N.I. 4) }\end{array}$ \\
\hline
\end{tabular}

Source: European Union agency for fundamental rights (2012).

Coercive medical measures are understood in legal doctrine as providing a person who has committed a crime in a state of limited sanity or insanity, or acquired such a state before sentencing or while serving a sentence, compulsory outpatient mental health care, as well as placement such a person in a special psychiatrist medical institution for compulsory treatment and in order to prevent this person from committing new socially dangerous acts (Pukavskyi and Kushpit, 2019). Given the above, the primary task of applying coercive medical measures is not to criminalize the person who committed the crime, but to ensure the comprehensive safety of criminals with mental disorders, as well as other individuals and society from potential socially dangerous acts of these criminals. Although the wording of coercive measures of a medical nature applied to persons who have committed a crime in a state of insanity or limited sanity, or acquired such a state before sentencing or while serving a sentence, are not identical in the criminal law of different countries, but they are similar in essence.

Analysis of the national criminal legislation of a number of countries in terms of regulating the use of coercive medical measures allows us to identify common and distinctive features of the regulatory enshrinement of this institution. In general, the comparison found that the regulation of the application of coercive medical measures to persons who have committed a crime in a state of limited sanity or insanity, has more common features than 
differences in the criminal codes of individual countries. In particular, the priority is given to the protection of the person of a criminal suffering from mental disorders over the protection of society, which is a manifestation of democracy and humanism. The grounds for the application of coercive medical measures to this category of persons are determined within this approach, which essentially coincide in nature in different criminal laws, as well as in accordance with criminal law doctrine (see Figure 1).

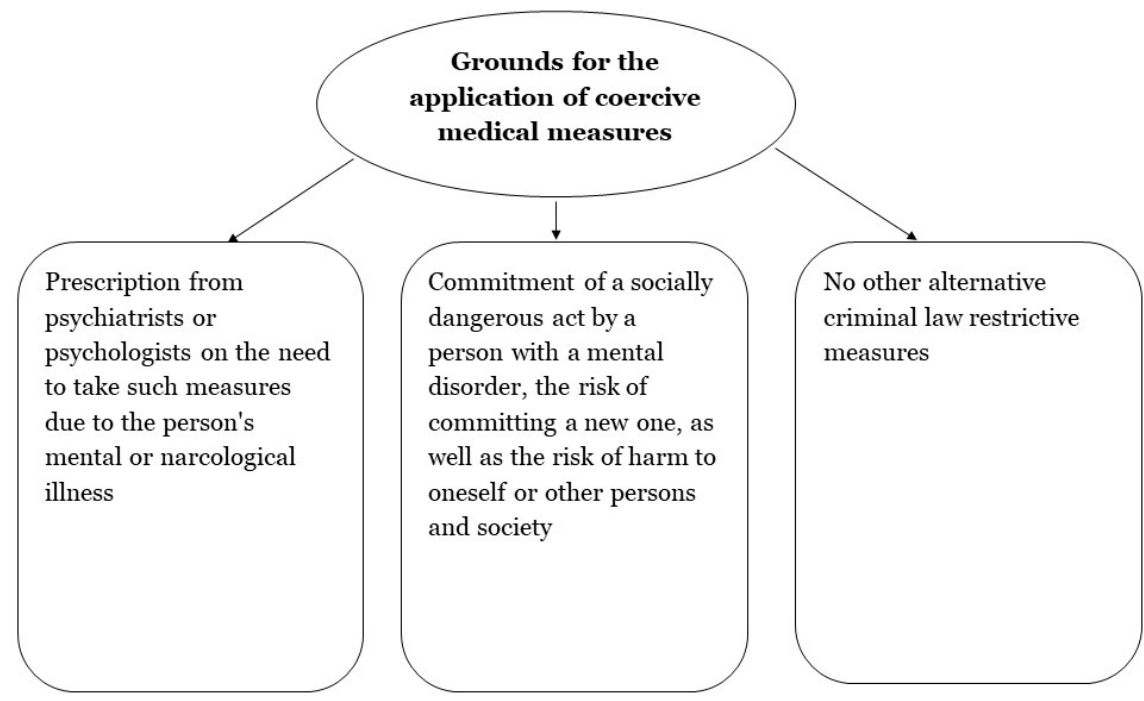

\section{Figure 1: Grounds for the application of coercive medical measures. Source: European Union agency for fundamental rights, (2012).}

National criminal law usually determines types of coercive medical measures, which are not always applicable to a person who has committed a crime in a state of limited sanity or insanity, or acquired such a state before sentencing or while serving a sentence, compulsory treatment. The types of coercive medical measures usually differ. They include, as a rule: outpatient observation of criminals with mental disorders; general-type psychiatric institutions; specialised medical psychiatric institutions with an enhanced regime of supervision (guard); public and private rehabilitation centres.

Despite a rather detailed legal regulation of the grounds and procedure for the application of coercive medical measures to criminals who were in a state of limited sanity or insanity at the time of committing the crime or 
acquired such a state before sentencing or while serving a sentence, there are a number of complications regarding their application in practice. This is primarily because such measures (as other criminal law measures to influence criminals) are to apply certain restrictions to the subjects of crime on their rights and freedoms. In particular, this applies to such rights enshrined in the Convention as the right to liberty and security of person (Article 5); the right to a fair trial (Article 6 of the Convention); the right to respect for family and private life (Article 8 of the Convention) (see Table 3).

\section{Table 3. ECHR decisions on violations of the Convention in the application of coercive medical measures and compulsory treatment}

\begin{tabular}{|c|c|}
\hline $\begin{array}{l}\text { Article of the European } \\
\text { Convention for } \\
\text { the Protection of } \\
\text { Human Rights and } \\
\text { Fundamental Freedoms }\end{array}$ & ECHR judgement \\
\hline $\begin{array}{l}\text { Article } 5 \text {. The right to } \\
\text { liberty and security of } \\
\text { person }\end{array}$ & $\begin{array}{l}\text { Winterwerp v. the Netherlands }(24.10 .1979) \text {, } \\
\text { Ashingdane v. the United Kingdom, 28.05.1985 } \\
\text { Johnson v. the United Kingdom, 24.10.1997 } \\
\text { Aerts v. Belgium, 30.07.1998 } \\
\text { Nielsen v. Denmark, 28.11.1998: } \\
\text { Varbanov v. Bulgaria, 05.10.2000 } \\
\text { Herz v. Germany, 12.06.2003 } \\
\text { Nowicka v. Poland, O3.12.2003 } \\
\text { M.R.L u M.-J.D. v. France, 19.05.2004 } \\
\text { H.L. v. the United Kingdom, 05.10.2004 } \\
\text { Enhorn v. Sweden, 25.01.2005 } \\
\text { Schneiter v. Switzerland, 31.03.2005: } \\
\text { Storck v. Germany, 16.06.2005 } \\
\text { Gajcsi v. Hungary, O3.10.2006 } \\
\text { Filip v. Romania, 14.12.2006 } \\
\text { Gulub Atanasov v. Bulgaria, 06.11.2008: Shopov v. } \\
\text { Bulgaria, O2.09.2010 }\end{array}$ \\
\hline $\begin{array}{l}\text { Article } 6 \text {. The right to a } \\
\text { fair trial }\end{array}$ & $\begin{array}{l}\text { HODŽIĆ v. CROATIA (p. } 1 \text { Article 6) } \\
\text { H.F. v. Slovakia 08.11.2005 } \\
\text { Nenov v. Bulgaria, 16.07.2009 }\end{array}$ \\
\hline $\begin{array}{l}\text { Article } 8 \text {. The right to } \\
\text { respect for family and } \\
\text { private life }\end{array}$ & $\begin{array}{l}\text { A.G. v. Switzerland (09.04.1997: } \\
\text { Storck v. Germany (16.06.2005) } \\
\text { Schneiter v. Switzerland (31.03.2005: } \\
\text { Shopov v. Bulgaria (02.09.2010 } \\
\text { X. and Y. v. the Netherlands, 26.03.1985 } \\
\text { Bensaid v. the United Kingdom, 06.02.2001 } \\
\text { K. u T. v. Finland, 12.07.2001 } \\
\text { Shtukaturov v. Russia, 27.03.2008 } \\
\text { Berková v. Slovakia, 24.03.2009 } \\
\text { Salontaji-Drobnjak v. Serbia, 13.10.2009 }\end{array}$ \\
\hline
\end{tabular}

Source: European Court of Human Rights (n. d). 
The procedure for prescribing compulsory treatment or other coercive medical measures to criminals in need of medical supervision and treatment is quite often violated during law enforcement. In particular, this is evidenced by the case law of the European Court of Human Rights. Involuntary medical intervention against a person's will in his or her private life is in essence a violation of the right to privacy and inviolability (Hirvisaari v. Finland, application no. 49684/99, judgment of September $27,2001)$, but if it was used to protect both the person himself/herself, and others, their use is justified by law.

The ECHR also ruled on June 16, 2005 in Storck v. Germany on the unlawful use of coercive medical measures to a person against his will, although it was later revoked because it became clear that the treatment permit and the contract with the medical institution was concluded by his representative in compliance with the law. Similarly, the judgment of March 31, 2005 in Schneiter v. Switzerland did not satisfy the person's claim, as it was found that the compulsory treatment was justified by law and pursued the aim of protecting the rights and freedoms of third parties. Instead, the ECHR ruled on 9 April 1997 in the case of A.G. v. Switzerland on the unlawful placing a person in custody, as this was found to be an unlawful invasion of privacy; as in the judgement of September 2, 2010 in the case of Shopov v. Bulgaria on the illegal long-term involuntary psychiatric treatment, as there had been a violation of the right to respect for private life (the judgement had never entered into force).

There are cases when the court's decision to forcibly place a person who committed a crime in a state of insanity or limited sanity in a specialized institution for treatment was lawful, or that coercive medical measures were lawful, but the terms of detention in such an institution were violated (for example, ECHR judgement of May 28, 1985 in Ashingdane v. the United Kingdom and judgment of October 24, 1997 in Johnson v. the United Kingdom). It is also a violation of the grounds for the application of coercive medical measures and compulsory treatment to place in an inappropriate institution for the detention of ill offenders (for example, the ECHR judgement of July 30, 1998 in Aerts v. Belgium).

Besides, the application of coercive medical measures or compulsory treatment violates other rights of persons who have committed a crime in a state of limited sanity or insanity, or acquired such a state before sentencing or while serving a sentence. In particular, according to the judgment of the European Court of Human Rights of March 24, 2009 in Berková v. Slovakia, the applicant's right to apply for restitution after receiving appropriate treatment for a mental disorder had been violated. There are also cases of failure to provide sufficient opportunities to ensure self-defence against arbitrariness (ECHR judgment of January 5, 2000 in Varbanov v. Bulgaria); the impossibility to challenge involuntary hospitalization because of the 
Iryna V. Kalinina, Volodymyr M. Kuprïenko, Iryna I. Shulhan, Dmytro O. Pylypenko y Olena A. Kozeratska

restriction on the filing of an application for an unlawful decision in the case (unfinished trial since 2011 in Aleksandr Petrovich Lashin v. Russia), etc. (European Court of Human Rights, n. d.).

This state of affairs indicates the need to improve the legislative regulation of the grounds and procedure for regulating the application of coercive medical measures to criminals who need it, from the standpoint of ensuring respect for fundamental human rights and freedoms.

Article 5 of the Convention stipulates that "Everyone has the right to liberty and security of person. No one shall be deprived of his liberty save in the following cases and in accordance with a procedure prescribed by law (Part 1); and paragraph "e" of this rule states that such a legal case is, among other things, is "the lawful detention of persons to prevent the spread of infectious diseases, lawful detention of persons of unsound mind, alcoholics or drug addicts or vagrants."

With the development of society, the development of humancentred legislation and the approach to guaranteeing human rights and fundamental freedoms, the interpretation of this provision also changes towards humanization, individualization and proportionality (compliance). In particular, the conduct of new psychiatric research allows and even requires changes in existing legislation, in particular with regard to the use of coercive measures for the treatment of mentally ill criminals. For example, the latest developments in psychiatry and psychology allow the use of more flexible means of treating mental disorders and diseases, as well as able to change society's attitude to such diseases and those who have them. Similarly, the development of neuroscience in psychiatry and psychology allows for the use of softer and more humane methods of compulsory treatment and supervision of persons with mental disorders who have committed a crime (Hafner, 2019).

Taking into account the content of complaints and decisions of the European Court of Human Rights regarding human rights violations in the application of coercive medical measures, as well as to humanize and comply with the principle of proportionality, we propose to include the following in the grounds for application of the said criminal law measures:

- recognition of the person who committed the crime as having a real mental disorder, based on the conclusions of an objective impartial medical examination.

- the nature and degree of mental disorder in the person who committed the crime must be such that it requires the use of a specific medical technique.

- hospitalization of a person who has been declared mentally ill may not continue if it has been established that the mental disorder has ceased, even if the period of treatment has not expired. 
There should also be a legal recommendation for national courts to apply the case law of the European Court of Human Rights to decisions in cases involving violations of the rights of criminals with mental disorders who have been subjected to coercive medical measures. This will avoid the typical mistakes made by courts in this category of cases. When applying these criminal law measures, a requirement should be established for the courts to clearly state the terms and type of the measures in the conclusions on the application of coercive medical measures.

The application of any criminal law measure must comply with the principles of criminal law and not violate human rights and freedoms. Therefore, the application of such measures should be necessary and sufficient to achieve the goal of their application - recovery, rehabilitation and loss of public danger of a person with mental disorders who committed the crime. Therefore, the possibility of early termination of the application of coercive medical measures should be regulated by law in the event that such a patient is cured and no longer needs medical care.

These recommendations should be enshrined at the level of international (in the Principles for the Protection of Persons with Mental Illness and the Improvement of Mental Health Care) and national (in criminal law and criminal procedure law) legislation.

\section{Discussion}

Given the above, the application of coercive medical measures against persons who have committed a crime while suffering from certain types of diseases as a criminal measure is a socially necessary step. The application of such measures is rightly considered an instrument of public (in terms of protecting society and other people) and personal (in terms of protecting the person in need of treatment) security in modern society (Dos Reis and Guareschi, 2016). This step is quite justified both from the standpoint of protection of human rights and freedoms, despite the compulsion to treat people with mental disorders, drug addiction, alcoholism (Israelsson et al., 2015), and from the perspective of security (Pukavskyi and Kushpit, 2019).

But coercive medical measures should be applied to the extent necessary and sufficient to assist and ensure safety (Reitan, 2016). Therefore, the expediency of applying certain coercive medical measures is rather doubtful. In particular, the use of chemical castration of certain types of criminals is unacceptable (even in case of paedophilia and similar crimes) (Zhuang, 2018), because such a medical measure to prevent crime is not only the correction and re-education of the convict, but also intervention in physiological processes that violate the rights of these persons. It is also unacceptable to use repressive measures during compulsory treatment of 
perpetrators, as it is an unjustifiably cruel measure and abuse that violates human rights and contradicts the provisions of the Convention for the Protection of Human Rights and Fundamental Freedoms (Windle, 2017).

The position on the complete refusal to use coercive medical measures as measures of criminal law influence on persons who have committed a crime is contradictory. The refusal of their compulsory treatment and the use of social care for them as other patients who did not commit a crime is contrary to the rights of the latter, and it will pose a threat to personal and public safety (Ferracuti et al., 2019). Nor can we agree with the position that compulsory treatment of drug and alcohol addicts violates the rights of the latter and is ineffective (Lövgren, 2021; Lunze et al., 2016), as these individuals are not fully able to control and realize their actions, which also poses a threat to both those individuals and society.

Instead, it is appropriate to consider the treatment of persons with mental disorders, alcoholics and drug addicts (including those who have committed crimes) compulsory, but the use of such coercive measures must be clearly justified, and the threat that may arise in the absence of such measures can harm the lives and health of these and other individuals (Pasareanu et al., 2017). Therefore, stricter and clearer criteria for the use of compulsory treatment of persons in mental health care institutions (Zinkler, 2016), as well as a mechanism for the use of compulsory treatment of perpetrators (Brochu and Levesque, 1991) should be developed at the national and international levels.

\section{Conclusions}

The study leads to the conclusion that the use of coercive medical measures in their legal meaning and wording does not violate international and national law in the field of human rights and freedoms. But there are certain violations and problems in the practical application of criminal law governing the use of coercive medical measures.

According to the results of the study on the legality of coercive medical measures, a number of proposals and recommendations were made to improve the practical application of these measures: expand the range of grounds for coercive medical measures, including the following:

a) recognition of the person who committed the crime as having a real mental disorder, based on the conclusions of an objective impartial medical examination.

b) the nature and degree of mental disorder of the person who committed the crime must be such that it requires the use of a specific medical technique. 
c) the hospitalization of a person who has been declared mentally ill may not continue if it has been established that the mental disorder has ceased, even if the period of treatment has not expired (in the relevant provisions of national criminal law).

We also propose to regulate the possibility of early termination of the application of a coercive medical measure in the event that such a patient has been cured and no longer needs medical care at the legislative level (in the relevant provisions of national criminal law).

The next proposition is to establish in the relevant norms a requirement for the courts to clearly determine the terms and type of the measures in the conclusions on the application of coercive medical measures (in the relevant provisions of national criminal procedure legislation).

We suggest to encourage national courts to apply the case law of the European Court of Human Rights in cases involving violations of the rights of criminals with mental disorders that have been subject to coercive medical measures (Principle 20 of the Principles for the Protection of Persons with Mental Illness and the Improvement of Mental Health Care).

Making these changes in the relevant legislation will contribute to further humanization, individualization and proportionality in the application of criminal law measures.

This study is not exhaustive and does not address all issues related to the application of coercive medical measures to persons who have committed a crime in a state of limited sanity, insanity or acquired such a state before sentencing or while serving a sentence. Providing proposals to improve the legislation on the application of these criminal law measures open up prospects for further research in this area, which will improve the regulatory framework and the practical implementation of coercive medical measures.

\section{Bibliographic References}

BERSH, Anastasia Yakovlivna. 2017. Compulsory Measures of a Medical Nature: Legal Nature and Types. PhD thesis. National University "Odesa Law Academy,”. Odesa, Ukraine.

BROCHU, Serge; LEVESQUE, Mario. 1991. “Treatment of Prisoners for Alcohol or Drug Abuse Problems" In: Alcoholism Treatment Quarterly. Vol. 7, No. 4, pp. 113-121.

DEZA, Monica; MACLEAN, Johanna Catherine; SOLOMON, Keisha. 2019. Local access to mental healthcare and crime. Available online. In: https://econ.uconn.edu/wp-content/uploads/sites/681/2019/10/mh crime_paper_10_1_2019.pdf. Consultation date: 18/01/2021. 
Iryna V. Kalinina, Volodymyr M. Kuprïenko, Iryna I. Shulhan, Dmytro O. Pylypenko y Olena A. Kozeratska

DOS REIS, Carolina; GUARESCHI, Neuza Maria de Fatima. 2016. "Preventing juvenile delinquency: Compulsory hospitalization as a public security tool” In: SAGE Open. Vol. 6, No, 2, Art. 21582440166.

EUROPEAN COURT OF HUMAN RIGHTS n. d. European Court of Human Rights (Homepage). Available online. In: https://hudoc.echr.coe.int/ eng. Consultation date: 18/01/2021.

EUROPEAN UNION AGENCY FOR FUNDAMENTAL RIGHTS. 2012. Involuntary Placement and Involuntary Treatment of Persons with Mental Health Problems. Publications Office of the European Union, 64 p. Luxembourg.

FERRACUTI, Stefano; PUCCI, Daniela; TROBIA, Federico; ALESSI, Maria Chiara; RAPINESI, Chiara; KOTZALIDIS, Georgios D; DEL CASALE, Antonio. 2019. "Evolution of forensic psychiatry in Italy over the past 40 years (1978-2018)" In: International Journal of Law and Psychiatry. Vol. 62, pp. 45-49.

HAFNER, Miha. 2019. "Judging homicide defendants by their brains: an empirical study on the use of neuroscience in homicide trials in Slovenia" In: Journal of Law and the Biosciences. Vol. 6, No. 1, pp. 226254 .

ISRAELSSON, M, NORDLÖF, K; GERDNER, A. 2015. "European laws on compulsory commitment to care of persons suffering from substance use disorders or misuse problems - a comparative review from a human and civil rights perspective" In: Substance Abuse Treatment, Prevention, and Policy. Vol. 10, Art. 34, pp. 15-29.

KAMARULZAMANA, Adeeba; MCBRAYER, John L. 2015. "Compulsory drug detention centers in East and Southeast Asia" In: International Journal of Drug Policy. Vol. 26, No. 1, pp. S33-S37.

KOOIJMANS, Tijs; MEYNEN, Gerben. 2017. "Who establishes the presence of a mental disorder in defendants? medicolegal considerations on a European Court of Human Rights case" In: Frontiers in Psychiatry. Vol. 8, p. 199.

LAPSHIN, Valery; KORNEEV, Sergey. 2019. "Social distributional aspect of penal actions" In: Innovative Technologies in Environmental Science and Education (ITESE-2019). Vol. 135, Art. 04063.

LOSYCH, Serhiy V; RUTVIAN, Krystyna O. 2019. "Difficulties of applying compulsory medical measures to limited sane persons" In: Forum Prava. Vol. 55, No. 2. pp. 45-51. 
LÖVGREN, Oscar. 2021. Compulsory care for alcohol use disorder A historical \& ethical analysis. Availlable online. In: https://www.diva-portal.org/ smash/get/diva2:1581969/FULLTEXTo1.pdf. Consultation date: 18/01/2021.

LUNZE, K; IDRISOV, B; GOLICHENKO, M; KAMARULZAMAN, A. 2016. "Mandatory addiction treatment for people who use drugs: global health and human rights analysis" In: BMJ. Vol. 353, Art. i2943.

MARKAVA, Nastassia Markovna. 2017. "Compulsory medical measures in criminal law of neighbouring countries" In: Journal of Belarusian State University, Series: Law. Vol. 1, pp. 112-116.

MENTAL ILLNESS POLICY. 2005. More mentally ill persons are in jails and prisons than hospitals: a survey of the states. Available online. In: https:// mentalillnesspolicy.org/ngri/jails-vs-hospitals.html. Consultation date: 18/01/2021.

MORGAN, Robert D; FLORA, David B; KRONER, Daryl G; MILLS, Jeremy F, VARGHESE, Femina; STEFFAN, Jarrod S. 2012. "Treating offenders with mental illness: a research synthesis" In: Law and Human Behavior. Vol. 36, No. 1, pp. 37-50.

PASAREANU, Adrian R; VEDERHUS, John-Kåre; OPSAL, Anne; KRISTENSEN, Øistein; CLAUSEN, Thomas. 2017. "Mental distress following inpatient substance use treatment, modified by substance use; comparing voluntary and compulsory admissions" In: BMC Health Service Research. Vol. 17, Art. 5.

PUGH, Jonathan; DOUGLAS, Thomas. 2016. "Justifications for nonconsensual medical intervention: from infectious disease control to criminal rehabilitation“ In: Criminal Justice Ethics. Vol. 35, No. 3, pp. 205-229.

PUKAVSKYI, Yuriy A; KUSHPIT, Volodymyr P. 2019. "Characteristic of application of compulsory medical measures" In: Juridical Scientific and Electronic Journal. Vol. 1, pp. 161-163.

REITAN, Therese. 2016. "Commitment without confinement. Outpatient compulsory care for substance abuse, and severe mental disorder in Sweden" In: International Journal of Law and Psychiatry. Vol. 45, pp. $60-69$.

SAYA, Anna; BRUGNOLI, Chiara; PIAZZI, Gioia; LIBERATO, Daniela; DI CIACCIA, Gregorio; NIOLU, Cinzia; SIRACUSANO, Alberto. 2019. "Criteria, procedures, and future prospects of involuntary treatment in psychiatry around the world: a narrative review" In: Frontiers in Psychiatry. Vol. 10, Art. 271. 
Iryna V. Kalinina, Volodymyr M. Kuprïenko, Iryna I. Shulhan, Dmytro O. Pylypenko y Olena A. Kozeratska

SOARES, Ruben; PINTO DA COSTA, Mariana. 2019. "Experiences and perceptions of police officers concerning their interactions with people with serious mental disorders for compulsory treatment" In: Frontiers in Psychiatry. Vol. 10, Art. 187.

TYSHCHENKO, Olga I; LEIBA, Olena A; TITKO, Ivan A. 2019. "European standards of respect for human rights in the application of compulsory medical measures in criminal proceedings" Wiadomości Lekarskie. Vol. 72, No. 12, Sup. 2, pp. 2445-2451.

WERB, D; KAMARULZAMAN, A; MEACHAM, M.C; RAFFUL, C; FISCHER, B; STRATHDEE, S.A; WOOD, E. 2016. "The effectiveness of compulsory drug treatment: A systematic review" In: International Journal of Drug Policy. Vol. 28, pp. 1-9.

WINDLE, James. 2017. "A slow march from social evil to harm reduction: drugs and drug policy in Vietnam" In: Journal of Drug Policy Analysis. Vol. 10, No. 2, pp. 2015-1029.

XIONG, Haiyan; JIA, Jidong. 2019. "Situational social support and relapse: an exploration of compulsory drug abuse treatment effect in China" In: International Journal of Offender Therapy and Comparative Criminology. Vol. 63, No. 8, pp. 1202-1219.

ZHANG, Simei; MELLSOP, Graham; BRINK, Johann; WANG, Xiaoping. 2015. "Involuntary admission and treatment of patients with mental disorder” In: Neuroscience Bulletin. Vol. 31, pp. 99-112.

ZHUANG, Jin. 2018. "Chemical castration: international experience and chinese path to control pedophilia crimes" In: Advances in Applied Sociology. Vol. 8, pp. 575-597.

ZHUMANBAEVA, Nonna A; ALIMKULOV, Erbol T. 2019. "Proceedings on the application of compulsory medical measures to the insane" In: Journal of Actual Problems of Jurisprudence. Vol. 2, No. 90, pp. 115-124.

ZINKLER, Martin. 2016. "Germany without coercive treatment in psychiatry-a 15 month real world experience” In: Laws, Vol. 5, No. 1, pp. 15-26. 

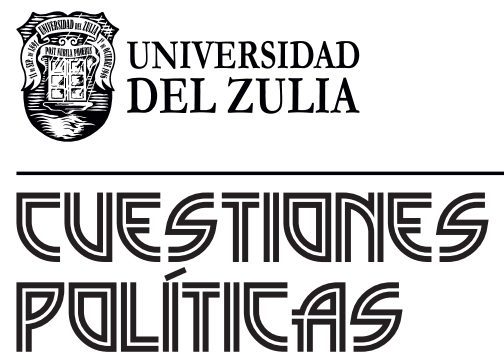

Vol. 39 N $^{\circ} 71$

Esta revista fue editada en formato digital y publicada en diciembre de 2021, por el Fondo Editorial Serbiluz, Universidad del Zulia. Maracaibo-Venezuela 